\title{
The Six Characteristics of Andragogy and Future Research Directions in EFL: A Literature Review
}

\author{
Diana Purwati ${ }^{1 *}$, Ainol Mardhiah ${ }^{2}$, Enung Nurhasanah ${ }^{3}, \&$ Ramli Ramli ${ }^{4}$ \\ ${ }^{1,3}$ STKIP Yapis Dompu, Nusa Tenggara Barat, Indonesia \\ ${ }^{2}$ STKIP Bumi Persada Lhokseumawe, Aceh, Indonesia \\ ${ }^{4}$ STKIP Taman Siswa Bima, Bima, Indonesia \\ *dianapw@stkipyapisdompu.ac.id
}

\author{
ARTICLE HISTORY \\ Received : 5 August 2021 \\ Revised : 14 December 2021 \\ Accepted : 2 January 2022
}

\section{KEYWORDS}

Andragogy

Adult Learning

Pedagogy

Theory of Learning

Literature Review

\begin{abstract}
The way in which adults learn is distinctive to how children learn, hence Andragogy differs from Pedagogy and so do the implications. Although several studies have attempted to discuss the andragogy and its principles, only few studies investigate its implementation and the practical guidance on how to employ each characteristic in the teaching and learning process. To fill this void, this paper reviews the concept of andragogy and highlights its six characteristics: self-concept, experiences, readiness to learn, motivation, need to know, and problem-centred learning. Employing a narrative review of 18 journal articles from reputable international journals, the study's findings suggest that the six characteristics/principles of andragogy are applicable in designing teaching and learning materials, teaching activities, and assignments enacted by teachers. Future research is encouraged to delve into the practice of the six characteristics of andragogy in the teaching of English as a foreign language. The differences between adults and children learning and directions for further research in teaching English as a Foreign Language (EFL) is also discussed at the end of study.
\end{abstract}

\section{Introduction}

Globalization has a significant impact on education particularly on the way adults learn English language. Many adults from different cultures and countries seek English tutors to enhance their English skills for some reasons, such as finding a job abroad, enhancing effective communication at work, improving social status or travelling around the world (Cozma, 2015). To meet these needs of learning English, lecturers and faculty members need to understand the theory of adult learning, called Andragogy. Knowles (1988) introduced the term andragogy which is composed of the Greek words for aner or "man" and "leader of". Andragogy literally means "leader of the human". In other words, andragogy alludes to the strategies to encourage and to facilitate adult learners in learning.

Malcolm Knowles, an American Educator, proposes the adult learning model, andragogy, that highlights six assumptions or characteristics; adults' self-concept, learning experiences, readiness to learn, motivation, need to know, and problem-centered learning. Educators who understand and implement six characteristics of andragogy in their teaching will assist adult learners to understand their own learning needs (Cochran in Cochran \& Brown, 2015). Not only does understanding the characteristics of andragogy assist educators to have a framework into practice, it also provides guidance for choosing the appropriate and contextual teaching-learning activities for adult learners at the tertiary level. There are many ways to explain how adults learn (Merriam et al. 2017), and to specify the difference between adults and children learning, several theories related to adult learning have been proposed: behaviorism, humanism, cognitivism, social cognitivism, constructivism, andragogy, transformative learning, and experimental learning. This paper, however, focuses on adult learning in the lens of andragogy.

Several studies have attempted to discuss the andragogy and its principles (Abdullah et al., 2021; Loeng, 2018), however, only few that review and provide practical implications on how to apply each characteristic in teaching and learning process (Ferreira \& Maclean, 2018) in particular related to online learning during the Covid-19 situations (Putri \& Elihami, 2021). Studies conducted by Loeng (2018) has clarified the concept of Andragogy and its difference concept between European and North American andragogy The study has also revealed and highlighted to the various perspectives systematically (Loeng, 2018). Another research conducted by Abdullah et al., (2021) has explored the concept of Andragogy according to Malcolm Knowles and its relevance to higher education in Indonesia. The study shows that the concept of Andragogy is applicable in promoting the higher 
education in Indonesia. Furthermore, Abdullah et al. (2021) suggest that the higher education concept in Indonesia should refer to the concept of Andragogy. However, these two studies have not discussed clearly the characteristics of andragogy and how to incorporate these characteristics into teaching and learning practices. In terms of the application of the Andragogy characteristics into teaching practice during Covid-19 pandemic in Indonesia, this has been held by Putri and Elihami (2021). Although the study has already discussed the theoretical framework of andragogy and pedagogy in developing e-learning during Covid-19 situation, this study does not clearly show the practical guidelines on how educators can apply the concept into their practices during Covid-19. The study conducted by Putri and Elihami (2021), furthermore, does not discuss the role of andragogy assumptions that highlight adult learners' needs. Therefore, in order to fill this gap and address adult learners' needs, this study reviews the concept of six assumptions of andragogy and provide suggested examples of practical implications for each of its assumption.

\section{Literature Review}

\subsection{Andragogy and Pedagogy}

Andragogy is a theory of learning focusing on assisting adult learners to learn (Knowles, 2005). Even though many people assume that the term of Andragogy was first introduced by Malcom Knowles, this actually was first coined by Alexander Kapp, an educator from German, in 1833 (Note et al., 2021). This theory of learning then was popularized by Malcom Knowles in the 1960s in the USA, and many scholars called him as "The Father of Andragogy" (Mews, 2020). This term came from Greek; in which andro means "man" and agogus means "leader of" (Mews, 2020). Andragogy is then defined as "the art and science of helping adults learn" (Knowles, 1980, p. 42).

In the process of understanding adults' learning, Andragogy has six learning principles as follows (Knowles, 2005): the need-to-know reasons of why adults learn something, self-concept of adults that is higher than children, more experiences in adults and reliance on these experiences in learning, adults' internal motivation, readiness to learn, and orientation in learning. The employment of these six characteristics would be beneficial for both students and teachers, in designing teaching and learning processes that will meet with adults' needs and autonomous. The example and its implementation will be elaborated clearly in the Result Section.

In Indonesian educational context, the current research of andragogy in both school and university level has been studied. Sumule (2018) discusses the implementation of Andragogy principles at a theological school. This shows a different perspective of the implication of Andragogy in language teaching at different context. He argues that Andragogy can be useful for students at theological schools such as Sunday School for Christian students as the use of andragogy on this context will help develop the program. However, this study has not systematically discussed on the application of andragogy in this non-formal educational setting. Similarly, research conducted by Syamsuddin and Jimmi (2018) show that six characteristics of Andragogy have clearly improved students' English skill. This study, however, does not clearly indicate how each principle was applied in the classroom.

Another study reviews the reorientation of andragogy in higher educational level. Abdullah et al. (2021) suggest that andragogy should be employed in higher education in Indonesia since thisadult learning theory fulfill adults' learning needs and characteristics. Similarly, at the tertiary educational context, the study conducted by Purwanti (2017) shows that the principles of andragogy have also plays essential roles on lecturers' perceptions regarding their professional learning and practices. Based on these three studies, it can be concluded that andragogy is not merely applied for adult learners in formal setting, such as in university level, but it also can be implemented for adult learners in non-formal educational settings.

While andragogy is focusing on helping adult learners in learning, pedagogy is a term used in children's learning. Pedagogy was developed for teaching children (Knowles et al., 2005). In contrast to adults acted as the center in their process of learning, the paradigm of pedagogy highly relies on dependency since children are claimed as learners who lack of knowing and experience (Nagara, 2020). However, andragogy and pedagogy have different characteristics or principles of learning. The results of this study will define these differences.

\section{Method}

This study incorporates semi-systematic literature review. This type of review is also known as a narrative review approach (Synder, 2019) that is designed for reviewing different types of topics and these topics have been conducted by diverse groups or researchers (Wong et al., 2013). To find supported and relevant literature, keywords such as 'andragogy', 'pedagogy', and 'adult learning' had been utilised in order to reach information from various journals and databases. Using these keywords and selecting the publication year between 2016 and 2021 , the researchers selected and reviewed 18 relevant journal articles from a total of 16,100 results. The main reasons why these 18 peer-reviewed articles were chosen due to the current issue, quality, relevance.

\section{Results}

The following sections review each characteristic of andragogy and analyze the implementations of each characteristic in the process of teaching and learning. 


\subsection{Self-Concept}

The first assumption of Andragogy is that adults have much more self-concept in learning compared to children. Knowles et al. (2005, p. 65) explain that 'adults have a selfconcept of being responsible for their own decisions, for their own lives'. This is because adults are mature, and are more self-determined and independent (Merriam \& Bierema, 2014). To enhance adults' self-concept in educational learning, Knowles, as cited in Merriam and Bierema (2014), highlights two pivotal factors for enhancing adults' learning. Firstly, it is important to establish a 'climate setting' meaning to create a comfortable learning environment and atmosphere. Secondly, it is essential to involve adults in designing the content of courses so that they can measure their expectations in courses. Involving adults' expectations in organizing the learning materials is also associated with the concept of self-directed learners in which adults take initiatives in the contributions of learning. Students who adopt the selfdirected learners would be able to develop their learning autonomy and be involved in taking decisions on what they learn (Loeng, 2020).

The implementation of the first assumption at the tertiary level can be seen from how universities design a standard or a norm that underpins adult learners in teaching and learning. Taylor and Kroth (2009) state that one of the ways to support adult learning at university is by incorporating adult's life experiences in the classroom since their experiences are fundamental. To apply this first assumption in the classroom, adult students are involved in rearranging the classroom setting before starting learning. The lecturer, for instance, can ask adult learners to arrange the chairs and tables which can support the communication between adults and the lecturer. Moreover, the lecturer can ask adults' expectations for the next meeting of the course after finishing each topic. Lecturer, furthermore, should analyze adult learners' needs by conducting need analysis at the initial meeting because this activity would assist them to meet with their learning needs. Needs analysis is an activity for gathering the information from learners in order to the curriculum design meet with students' expectation, needs, and autonomous (Hariyadi \& Yanti, 2019).

In virtual teaching and learning, particularly during covid 19 pandemic, the application of self-concept can be applied by conducting need analysis before online class started. The lecturers may arrange a simple questionnare which consist of several questions for checking adult learners' expectations and needs. Checkingstudents' expectations through the analysis need before virtual learning started may allow lecturers to design materials and methodologies that compatible with students' needs in their online classes. The lecturers, in addition, may incorporate technological platform in order to enhance students' engagements. Kahoot, for instance, is one of educational platforms to facilitate distance learning. The lecturers may use Kahoot in both practice and review the students' understanding during the remote learning conducted. Licorish (2018) highlights that Kahoot application offers a different learning atmosphere, attracts students' attention, and makes students more focused on the lessons. Therefore, involving adult learners through some activities, such as conducting a need analysis, setting the class, incorporating technological platform, and asking their learning expectations and needs will help adults to enhance their self-concept in learning.

\subsection{Experiences}

The second assumption of Andragogy is that adults have rich experiences which can impact their ways of learning (Knowles et al., 2014). Pitts (2013) points out that personal or professional past experiences will assist students' progression in learning. Likewise, Boud and Miller (1996) note that experience is the foundation of all learning because it optimizes the opportunity of adults to learn. Therefore, experience in learning plays an essential role to support both lecturers and adult students in teaching and learning.

Adults maintain their experiences based on the concept of 'who they are' when they learn new knowledge by comparing and contrasting (Merriam \& Bierema, 2014, p. 50). Consequently, adults tend to object or question new information, and a traumatic experience can impede their learning. Hence, varied backgrounds of adults have an influence in learning. Since adults' experiences have been the main resources of adults' learning, Purwanti (2017) argues that teachers should explore and understand adults' experiences as this information plays an essential role in assisting adult learners meet their needs. Moreover, this information would assist teachers to select appropriate learning materials for adults to support and optimize their learning.

For the application of this second assumption at university, lecturer can employ innovative teaching techniques to meet adult learners' experiences and learning. Tandon (2016) in his book Innovative Pedagogy, defines two innovative activities which might be useful for lecturers. Firstly, Outdoor Event Preparation, an event which can be conducted outside the educational programs such as exhibitions, consumer fair, and trade fairs. Through this outdoor activity, adult learners can learn specific skills such as negotiation or selling skills which will be beneficial to maintain their experiences in learning. Secondly, RealTime Business Commencement, which is useful to boost students' entrepreneurship skills. Lecturers may also help learners to maximize their experiences in this process by asking their past experiences in organizing these events. Asking this information would be useful for the improvement of adults' experiences as they more rely on their experiences in learning (Pitts, 2013). Both outdoor 
activities can be developed by educators to enhance adult learners' experiences.

The incorporation of adults learners' experiences in virtual learning during covid-19 can be done by the utilization of videos and projects. In online learning activities, lecturers may post videos related to the topics of learning and have them express their opinions in a small discussion group by including and comparing their personal stories and experiences. To support the use of video, the lecturers may design a simple project to engage students learning activities based on meaningful to-do in the real-life (Project-Based Learning). This could be conducted by asking students to make a simple project related to the topic of learning, such as producing and sharing a video how to cook healthy food. The adult learners can present the result of their project via Zoom meeting, Google Meet, You Tube, or post it to their social media.

\subsection{Readiness to Learn}

The readiness of adults to learn can be affected by social and professional developments referring to their social roles in certain communities such as friends, co-workers, and so on (Merriam \& Bierema, 2014). These social roles are seen as an opportunity for a 'teachable moment', a specific time for adults to enhance skills in order to cope with new challenges (Merriam \& Bierema, 2014).

In applying this third assumption in a classroom, Watkins (2005) suggests lecturers to ask adult learners' specific experiences related to topic or course content and their expectations. This can be applied by facilitating learners to have a discussion which also will enhance their engagement. In addition, learners can also be encouraged to reflect and to organize their thoughts after the discussion then presenting the result of the discussion in a small group or in front of the class. These learning activities may also be applicable in the online learning, particularly during Covid-19 situation. To facilitate e-learning and readiness in learning, educators may ask adult learners to choose a particular case study that reachable in their circumstances. After choosing the case study, the lecturers divide adult learners into some groups by creating a simple poster, then asking them to present virtually via Zoom or any supporting technological tools for learning. Lectures may ask other students to give inquiries and feedbacks. These activities would help adult learners to gain readiness for learning since they should prepare their presentations.

In order to implement this third Andragogy characteristic, educators need to equip themselves with knowledge and understanding on self-directed readiness tools to check students' readiness (Gencel \& Saracaloglu, 2018) so that they are able to utilize these learning tools to direct self-directed readiness for their students. In other words, to support the implication of andragogy, readiness to learn, educators should equip themselves with supporting skills, such as the use of technological advances.

\subsection{Motivation}

Dörnyei (2020) clearly argues that motivation refers to the psychological conditions of people's thought, or any related factors that affect people's actions and thoughts. The role of motivation is pivotal in education. Purwati (2020) argues that motivation remains essential for supporting learners in learning. In terms of adults' motivation in learning, adult learners are intrinsically motivated to learn (Knowles et al., 2005). Internal motivations, such as quality of life and job satisfaction are more effective on adults than that of external factors such as having better jobs and higher salary (Knowles et al., 2014). However, it is too general to claim that all adults are merely influenced by internal motivation. Merriam and Bierema (2014) point out that not all adult learners are intrinsically motivated since other external factors such as duties on job or participation in training can be the reasons why adults are highly motivated to learn. Misch (2012) reports that despite the fact that medical students, for instance, are both internally and externally motivated in learning, such as in following governmental and professional regulations. When medical students are to obtain a medical license, they have to pass the national examination, or if they have high enthusiasm to become a physician, they have to finish their medical school (Misch, 2012). Thus, it is clear that adults' motivation to learn is not merely affected by the intrinsic motivation, but external motivations also play an essential role in their learning.

To improve adults' motivation in learning, Aragon (2003) suggests educators to establish a supportive learning environment where learners can participate actively. This can be done by encouraging learners to respect, to appreciate, and to value others' opinions (Blondy, 2007). To apply these values, lecturers should employ a communicative teaching strategy that can encourage adult learners to have a discussion. In an online classroom setting, lecturers, for instance, may ask adults to join an international webinar, take notes of important points, and let them to discuss via Zoom or other supporting platforms with their peers. After discussions, lecturers may suggest their adult learners to write the result of the discussion in a local newspaper or create a video so that other people can reach their opinions. Furthermore, Merriam and Bierema (2013) mention that instructors can link adults' needs and interests with the learning content, so that they become internally motivated. Based on these suggested implications, it can be highlighted that in order for boosting adults' motivation in learning, lecturers should design learning activities that can engage learners to participate actively in both online and offline classroom settings. 


\subsection{Need to Know}

Another characteristic of Andragogy is that adults must know the reason why they learn new knowledge, as their learning orientation will drive their engagement in learning. Knowles et al. (2014) underline that before adults decide to learn, they will think of both benefits and consequences. Therefore, it is pivotal for lecturers who teach adult learners to explain and to give reasons why they learn the courses (Knowles et al., 2014). Explaining reasons and the importances of learning courses before learning will be essential in enhancing students' learning awareness. It is the main duty of facilitators to assist adult learners in having awareness to learn a particular topic (Merriam \& Bierema, 2014).

The implication of learning strategies and activities plays an essential role to help adults aware of their learning orientation. This can be done by incorporating learning activities such as case studies, conducting interviews, and problem-solving activities for capturing their learning orientation (Conrad \& Donalson, 2004). These Task-Based Activities are practical since they provide learners with real-life experiences (Knowles et al., 2005). The implementation of learning activities, such as conducting interviews and problem solving tasks, is also applicable in virtual learning by driving adults with a critical question. For instance, lecturers may ask: How can parents assist young learners to study online effectively in their home? After posting this problem, adults may interview their neigbours in order for overcoming the problems and guiding them to collect the data. Likewise, Domysheva and Kopylova (2021) note that it is of paramount importance to provide practical activities based on real-life situations and adult learners' job-related duties. For example, when designing speaking activities, educators should build problems that have to be solved in a discussion. Furthermore, the first meeting of class can also be used for checking adults' learning orientation. At the initial class meeting, educators may start explaining the content of the course and ask their reasons why they learn the course.

\subsection{Problem-centered Learning}

Merriam and Bierema (2014) clearly state that adults are problem-centered, and there are two basic reasons why adults are problem-centered. First, when adults bring an issue to their learning, they will have a motivation to learn (Merriam \& Bierema, 2014). For instance, when an adult is diagnosed with Covid-19 and his/her health has been deteriorated because of this virus, it will drive the adult to find more information about this virus, the treatment, medicine, or way control his/her daily intake. This condition is called problem-centered as an adult learns based on the problem that he/she has. This first reason correlates with the previous characteristic namely internal motivation.
Another reason why adults are problem-centered is because learning through problem is more engaging and applicable in real-life situation (Merriam \& Bierema, 2014). Although adults are mature and have experiences, the role of facilitators in guiding problem-centered learning is still needed. Regarding the role of facilitators, teaching adults in problem-centered learning is different from teaching adults in traditional classes. While an educator tends to be the source of learning in traditional classes, an educator acts as a facilitator in problem-centered learning (Rico \& Ertnmer, 2015). Similarly, Schwartz cited in Rico and Ertnmer (2015) states that during the discussion process of problemcentered learning, the educator acts as a facilitator, not as the expert of information. Incorporating this sixth principle in teaching online can be developed by encouraging adults to have a discussion that present multiple views from experts and their classmates via Zoom or supporting learning tools. To facilitate adults' understanding, engagement, and interpretation of the issue, the lectures can use the polling features of Zoom. For instance, before the discussion conducted, the lectures can inform to adults to post some questions then ask other students to respond the queries using the polling features. The use of polling in the online discussion would help lecturers to check students' engagement and assist adult learners in taking decisions on the issue that is being discussed.

Educators should encourage learners in making decision through problem-based learning in which they take responsibility for their own learning while enhancing their own self-directed learning skills (Abraham et al., 2016). Using problem-based learning approach, a study conducted by Hadi and Izzah (2018) reveals that the students become more open and comfortable to share their problems in learning English resulting in a better self-regulation by creating strategies and plans to improve their English collectively in both face-to-face and virtual classes.

\subsection{The Difference between Andragogy and Pedagogy}

In accordance with the six assumptions and the difference between andragogy and pedagogy, it can be highlighted that there are several significant differences between andragogy and pedagogy (Hughes et al., 2013). Firstly, in terms of learning orientation, in pedagogy, children tend to study in order to pass tests while adults tend to have reasons why they learn something. Secondly, in pedagogy, the teaching and learning process must be guided by teachers while adults tend to be self-directed in learning.

The third difference is learners' experiences. In pedagogy, children seem to have fewer experiences than adults who have varied experiences. This is in line with O'Shea's (2016) study finding that age impacts selfdirected learning as adults at 25 years and older have higher learning experiences allowing them to be more self-directed 
in learning. The fourth difference is on the readiness to learn. While the readiness of children depends on teachers' preparations, adult learners are often driven by their willingness to learn something new related to their real life. The fifth difference is students' orientation in learning. In pedagogy, children learn based on the curriculum content, but adult learners are self-oriented. The last is students' motivation. In this factor, the difference is visible because children tend to be extrinsically motivated while adults are more intrinsically motivated.

Due to the differences in the way of adults and children learn, it is pivotal for educators to consider the six characteristics of andragogy when teaching adults. These can be done in several ways; conducting Outdoor Event Preparation, encouraging adult learners to rearrange the setting of their own classroom (Kroth, 2009), customizing their learning depending on their individual learning objectives (Domysheva \& Kopylova, 2021) and many other activities as mentioned in result-analysis section. It is also important to note that the application of six characteristics of andragogy should also involve adults' experiences, expectations, and needs in designing the learning activities and materials as it would be the useful information for teachers.

In a nutshell, the difference between andragogy and pedagogy is outlined in this following table:

Table 1. The outline of differences between andragogy and pedagogy

\begin{tabular}{|c|c|c|}
\hline Characteristics & Pedagogy & Andragogy \\
\hline Self-Concept & $\begin{array}{l}\text { Children are more dependent to the } \\
\text { teachers in the teaching and learning } \\
\text { process. The teachers tend to be 'the } \\
\text { decision makers' in terms of decide } \\
\text { what and why children learning the } \\
\text { lesson }\end{array}$ & $\begin{array}{l}\text { Adults are more self-directed and } \\
\text { responsible in their learning as they } \\
\text { are independent learners. }\end{array}$ \\
\hline Experiences & $\begin{array}{l}\text { Children are less experienced than } \\
\text { adults. Therefore, as the resource of } \\
\text { learning, they rely on the experience } \\
\text { from teachers. } \\
\text { Teachers might not able to employ } \\
\text { independent learning techniques in } \\
\text { this stage since children use teachers' } \\
\text { experiences during the process of } \\
\text { learning. }\end{array}$ & $\begin{array}{l}\text { Adults have more experiences and } \\
\text { they rely on their experiences as the } \\
\text { resource during the process of } \\
\text { learning. } \\
\text { To explore adults' experiences, } \\
\text { teachers/lecturers may employ } \\
\text { independent learning methods. }\end{array}$ \\
\hline Readiness to learn & $\begin{array}{l}\text { Children need to wait for the } \\
\text { instruction of teachers related to what, } \\
\text { why, and how to learn. }\end{array}$ & $\begin{array}{l}\text { The readiness of adult learners in } \\
\text { learning is also dependent on the } \\
\text { social and professional environment. }\end{array}$ \\
\hline Motivation & $\begin{array}{l}\text { Young learners are driven by external } \\
\text { factors in learning, such as parents, } \\
\text { friends, or their teachers. }\end{array}$ & $\begin{array}{l}\text { Adults are motivated by both intrinsic } \\
\text { and extrinsic motivations, such as } \\
\text { salary, job satisfaction, and etc. }\end{array}$ \\
\hline Need To Know & $\begin{array}{l}\text { Young learners do not need to know } \\
\text { the reasons why they learn particular } \\
\text { lessons as they more highly rely on } \\
\text { their teachers in guiding them. }\end{array}$ & $\begin{array}{l}\text { Before learning, adult learners need to } \\
\text { know why they have to learn } \\
\text { particular subjects. }\end{array}$ \\
\hline Problem-Center Learning & $\begin{array}{l}\text { Teachers can use teacher-centered } \\
\text { learning, curriculum-based learning } \\
\text { and other types of teachers learning } \\
\text { center. }\end{array}$ & $\begin{array}{l}\text { In teaching adult learners, } \\
\text { teachers/lecturers can employ student- } \\
\text { centered learning, problem-centered } \\
\text { learning, performance-based learning }\end{array}$ \\
\hline
\end{tabular}

\section{Discussion}

Andragogy is a method that specifically focuses on supporting adults' learning addressing several characteristics of adult learning (Merriam \& Bierema, 2014). From the result section, it can be highlighted that the six principles of Andragogy can be applicable in designing teaching and learning materials, teaching methods, and assignments. It can be also pointed out that andragogy has six assumptions in describing adult learners' characteristics: 1) An adult is someone who has an independent selfconstruction (self-concept); 2) An Adult has more experience than children (experience); 3) An adult has a 
readiness to learn (readiness to learn); 4) An adult is highly affected by internal motivation than external motivation (motivation); 5) An adult often knows the reason why he/she learns something (need to know); and 6) An adult is a problem-centered rather than subject-centered (problemcenter learning) (Knowles as cited in Merriam \& Bierema, 2014). Similarly, Hughes and Quinn (2013, p. 13) argue that there are several general characteristics of adult learning: 1) The process of adults' learning is continuing, not starting; 2) Adults have a set of experiences; 3) Adults have knowledge and values; 4) Adults have aspirations and intentions in situational learning; 5) Adults have learning expectations; 6) Adults have a competing interest; 7) Adults employ phase of learning. The way scholars classify these characteristics may seems different but these actually imply similar meaning and characters.

This present study has suggested several examples of the applications of each principle of andragogy (see result section). The implication of every characteristic of andragogy requires the role of both lecturers and students, so that the practical implication of each Andragogy character can be done effectively. The implication of selfconcept principle, for example, requires lecturers' strategy and understanding in delving adult learners' prior knowledge. It is also essential to note that lecturers may employ more than one Andragogy principle in their teaching process as these principles are intertwined. The utilization of more than one Andragogy characteristic would be beneficial in enhancing the effectiveness of teaching strategy used by lecturers. For example, lecturers may apply self-concept, adults' experiences, and students' motivation principles together in both face-to-face classrooms and virtual classrooms. However, there are still limited literature discussing how to incorporate more than one andragogy's characteristics in the classroom. Therefore, further research on this topic is needed to analyze the effectiveness of its implementation in the classroom. The application of six characteristics of Andragogy requires the integration of supporting learning strategy and technology in order to meet learning objectives. For instance, the use of PBL (Project Based Learning) and Zoom, the utilization of Task-Based Learning and Kahoot, and other supporting teaching methods and tools.

With these characters of Andragogy, it is worth to note that learning happens differently on adults and young learners. While young learners might rely more heavily on the role of teachers, andragogy is the opposite. Bowling and Henschke (2020) state that Andragogy and Pedagogy are two learning models that have historical correlations in education and learning processes. They further explain that although pedagogy discusses both adults and children learning, it is more focused on children than adults. Even though several studies have attempted to analyze and to discuss andragogy and pedagogy in various different contexts such as education and business (Putri \& Elihami, 2021; Hägg \& Kurczewska; 2019; Sharifi et al., 2017), research focusing on pedagogy and andragogy that will analyze and discuss students' perspectives on the applications and usefulness of these two theory of leanings may need to be carried on.

Since this study also focuses on the six characteristics of andragogy at the tertiary level, these characteristics would also be important in encouraging lecturers or teachers in university contexts to optimize their professionalism. This is because teaching students at tertiary level is also categorized as teaching adult learners who rely on their independence and experience. The study conducted by Purwanti (2017) shows five emerging data on the lecturers' perception towards their professionalism. The lecturers' perceptions are in line with five principles of adult learning theory. These five perceptions are 1) teachers believe that learning as a mandatory activity for them, 2) learning affects teachers' experiences, 3) teachers have passion in learning, 4) learning as the orientation of teachers, 5) teachers learning due to internal motivation. What have been emerged in her study are similar to the five characteristics of andragogy; self-concept, experience, readiness to learn, orientation to learning, and internal motivation.

In terms of the future research of andragogy and pedagogy in EFL context, the application of these two different theories of learning needs to be classified. Teaching English as a Foreign Language (EFL) has been a common term that is applied in countries using English as a foreign language such as Indonesia, Thailand, China, and etc. In other words, this term is used for those who learn and teach English as an additional language in non-English speaking countries. In spite of the fact that the demand of learning English in Indonesia has been bloomed, EFL teachers still find it difficult to develop students' English communicative skill (Purwati, 2019). This can be influenced by both internal and external factors such as students' lexical resources, pronunciation, motivation, school facility, and so on (see Batubara et al., 2020; Nursafira, 2020; Nur Aisyah, et al., 2021). To assist EFL teachers to improve their professional capacity and practice, particularly in the rural area, it is essential to have special treatments referring to strategy and approach, learning materials, teaching methodology and learning speed (Saiful $\&$ Triyono, 2018). These factors can be linked to the six principles of andragogy. In order to reach the scientifically prove of these six characteristics of andragogy, further research needs to be conducted in regard to the incorporation of six characteristics of andragogy in EFL contexts because the study on this issue is still limited.

Several examples provided in this study might be applicable for any language learners and majors but these have not been entirely focused on EFL. Lavasani and 
Faryadres (2011) suggest that this might happen due to the lack of literature related to andragogy in EFL contexts and they then urge the need of one specific methodology according to adults' properties in the contexts of EFL. Thus, research focusing and providing real examples taken from English language learners' experiences are desirable to provide more meaningful implications.

This study has several limitations resulting in some directions for further research. First, the current research mainly focused on exploring the characteristics of andragogy implying the need to consider other aspects of andragogy, such as its advantages, disadvantages, gender, age, learning styles, beliefs and theories underpinned andragogy, its practical suggestions, and so on.

A study of Hubers et al. (2020) highlight only two characteristics of andragogy in their study suggesting that when designing a course for adult learners, in their case, a teacher development program, educators should match between learning goals and the designed activities. Although a study shows that the application of six principles andragogy has enhanced English students' skills (Syamsuddin \& Jimi, 2018), a study of Hiew and Murray (2021) find that six principles of andragogy were only partially implemented and the program did not completely address the learning needs and learning approaches of the adult learners. Besides, a study conducted in Saudi Arabia at Taif University revealed that students have different perspectives toward the characteristics of andragogy (Aljohani \& Alajlan, 2021). Therefore, further studies explaining how to apply each six assumptions of andragogy in the context of teaching English as Foreign Language (EFL) incorporating English Language Learners' needs and autonomy may become an interesting attribute to explore in EFL contexts.

Based on the application of each characteristic of andragogy, it is also important to note that there are methodological differences between pedagogy and andragogy as a result of neurological differences due to the difference of how adults and children's brain work (Point Park University, 2020). This implies the needs of different teaching material and utilized techniques when teaching people at different ages. Further study addresses teaching techniques and materials using andragogy approach highlighting the six characteristics should also be conducted to provide practical implications for educators teaching adult learners.

The implication of six characteristics of andragogy also encourages lecturers to use students learning in designing their teaching activities. Therefore, lecturers need to equip their teaching activities with different types of students learning center to engage the students. These kinds of techniques refer to project-based learning, discovery learning center, cooperative learning, and etc. The utilization of these teaching techniques is not only useful to optimize adult learners' experiences, but also to encourage adult learners to be more independent in learning.

In addition, the methodology of this study is limited, therefore, the employment of a more comprehensive methodology when approaching this issue should be considered. As has been argued by Note et al. (2021), in andragogy, it is free to employ any different types of methods for supporting the communication as long as these support the intervention and open the ways of people thinking.

\section{Conclusion}

Andragogy is a learning theory discussing the way to assist adults in learning. This study has explored the concept of Andragogy, reviewed its six characteristics, and provided several suggested implications on how to apply its characteristics in the teaching and learning processes. The suggested applications of the principle of andragogy have also adjusted to the teaching process of current pandemic situations. Many researchers have studied the implication of andragogy, but only a few studies discuss how to apply each six principles in both face-to-face and virtual teaching and learning processes. The implication of six characteristics of Andragogy, furthermore, can be integrated in teaching methods, designing learning materials, and structuring the assignments for supporting adults learning. The difference between Andragogy and Pedagogy as well as the direction for future research have also been discussed. The main differences of these two learning theories can be highlighted from the six characteristics of andragogy: learning experiences, learning orientation, learners' self-concept, readiness to learn, motivation, and students' orientation. Further study that primarily focuses on the implementation of six assumptions for English Language Learners (ELLs) in an English as a Foreign Language (EFL) context need to be conducted in order to provide more practical and meaningful implications for educators teaching adult learners in teaching.

\section{References}

Abdullah, M., Chamid, N., \& Khamim, K. (2021). Reorientation of the Andragogy Concept and Its Relevance to Higher Education in Indonesia for Answering the Global Era of Information: Critical Review of Malcolm Knowles Perspective. Paper presented at the 2nd International Conference on Islamic Studies, Ponorogo, Indonesia. Retrieved from https://eudl.eu/doi/10.4108/eai.27-102020.2304160 .

Aljohani, O. H., \& Alajlan, S. M. (2021). The application of andragogy for the advanced diploma program in education at Saudi Arabia's Taif university. International Journal of Information and 
Communication Technology Education, 17(3), 1-11. https://doi.org/10.4018/IJICTE.20210701.oa1

Aragon, S. R. (Ed.). (2003). Facilitating learning in online environments. San Francisco, CA: Jossey-Bass. Between Pedagogy vs. Andragogy. Point Park University.

Batubara, F., Derin , T., Putri, N. S., \& Yudar , R. S. (2020). Five Factors Influencing the Students' Motivation to Learn English as a Foreign Language: A Closer Look into Montessori Classroom Environment. REiLA : Journal of Research and Innovation in Language, 2(2), 76-84. https://doi.org/10.31849/reila.v2i2.3165

Bowling, J., \& Henschke, J. A. (2020). Pedagogy and Andragogy Intersection of Learning. In Rocco, T S. , Smith, C. M, Mizzi, C.R, Merriweather, L.R, Hawley. J.D (Eds.), The handbook of adult and continuing education. Stylus Publishing, LLC.

Cozma, M. (2015). The Challenge of Teaching English to Adult Learners in Today's World. Social and Behavioral Sciences, 197. http://doi.org/10.1016/j.sbspro.2015.07.380

Domysheva S. A., \& Kopylova N. V. (2021). Overcoming non-linguistic barriers to effective speaking in Russian adult ESP classroom. History, Pedagogics, Philology, $27 \quad$ (1), 87-94. DOI: http://doi.org/10.18287/2542-0445-2021-27-1-87-94

Dörnyei, Z. (2020). Innovations and challenges in language learning motivation. Routledge. https://doi.org/10.4324/9780429485893

Downing, J. J., \& Dyment, J. E. (2013). Teacher educators' readiness, preparation, and perceptions of preparing preservice teachers in a fully online environment: An exploratory study. The Teacher Educator,48(2),96109.Ferreira, D., \& Maclean, G. (2018). Andragogy in the $21^{\text {st }}$ century: Applying the assumptions of adult Learning Online. Language Research Bulletin, 32(September 2017), 10-19.

Gencel, I. E., \& Saracaloglu, A. S. (2018). The effect of layered curriculum on reflective thinking and on self-directed learning readiness of prospective teachers. International Journal of Progressive Education, 14(1), 8-20.

Goodnight, R., \& Zickel, T., \& Owen, D. O. (1999). Understanding Andragogy: How Adults Learn. Paper presented at 1999 Annual Conference, Charlotte, North Carolina. https://peer.asee.org/8010

Hadi, M. S., \& Izzah, L. (2018). Problem Based Learning (PBL) in teaching English for students of primary school teacher education department. English Language in Focus (ELIF), 1(1), 45-54.
Hägg, G., \& Kurczewska, A. (2019). Who is the student entrepreneur? Understanding the emergent adult through the pedagogy and andragogy interplay [Special Issue]. Journal of Small Business Management, 57, 130-147.

Hall, H. E. (2021). The Lived Experiences of the Midlife Learner in Pursuit of Higher Education as It Relates to Andragogy and Self-Directed Learning Approaches (Publication No. 28319102) [Doctoral dissertation, Northcentral University]. ProQuest Dissertations and Theses Global.

Hariyadi, A., \& Yanti, D.R. (2019). The importance of needs analysis in materials development. Jurnal Ilmiah Profesi Pendidikan, 4(2), 94-99

Hiew, W., \& Murray, J. (2021). Enhancing Huber's evaluation framework for teacher professional development programme. Professional Development in Education (Online First), 1-15.

Hubers, M. D., D. Endedijk, M., \& Van Veen, K. (2020). Effective characteristics of professional development programs for science and technology education. Professional Development in Education (Online First), 1-20.

Hughes, S. (2013). Quinn's Principles and Practice of Nurse Education (6th Edition). UK: Cengage Learning.

Knowles, M. S. (1988). The adult learner: A neglected species. London: Gulf.

Knowles, M. S., Holton III, E. F., \& Swanson, R. A. (2005). The adult learner: The definitive classic in adult education and human resource development (6th ed.). San Diego, CA: Elsevier.

Knowles, M. S., Holton III, E. F., \& Swanson, R. A. (2014). The adult learner: The definitive classic in adult education and human resource development. Routledge.

Lavasani, M. G., \& Faryadres, F. (2011). Language learning strategies and suggested model in adults processes of learning second language. ProcediaSocial and Behavioral Sciences, 15, 191-197.

Licorish, S. A., Owen, H. E., Daniel, B., \& George, J. L. (2018). Students' perception of Kahoot!'s influence on teaching and learning. Research and Practice in Technology Enhanced Learning, 13(1), 1-23.Loeng, S. (2018). Various ways of understanding the concept of andragogy. Cogent Education, 5(1), 1-15. https://doi.org/10.1080/2331186X.2018.1496643.

Loeng, S. (2020). Self-directed learning: A core concept in adult education. Education Research International 
(Online

https://doi.org/10.1155/2020/3816132

First), 1-12.

Merriam, S. B., \& Bierema, L. L. (2013). Adult learning: Linking theory and practice. John Wiley \& Sons.

Merriam, S. B., Caffarella, R. S., \& Baumgartner, L. M. Learning in adulthood: A comprehensive guide, (San Francisco, CA: John Wiley \& Sons/Jossey-Bass, 2007. Reflective Practice: Formation and Supervision in Ministry, 31.

Mews, J. (2020). Leading through andragogy. College and University, 95(1), 65-68.

Misch, D. A. (2002). Andragogy and medical education: Are medical students internally motivated to learn?. Advances in Health Sciences Education, 7(2), 153-160.

Nagara, Chanikarnda Komarakul Na. (2020). Pedandragogy: Promoting effective learning environments and self-efficacy in adult learners with andragogy and pedagogy (Publication No. 27829219) [Doctoral dissertation, Indiana University of Pennsylvania]. ProQuest Dissertations and Theses Global.

Note, N., De Backer, F., \& Donder, L. D. (2021). A novel viewpoint on andragogy: Enabling moments of community. Adult Education Quarterly, 71(1), 3-19. doi: https://doi.org/10.1177/0741713620921361

Nur Aisyah, R., Istiqomah, D. M., \& Muchlisin, M. (2021). Rising English Students' Motivation in Online Learning Platform: Telegram Apps Support. Utamax : Journal of Ultimate Research and Trends in Education, 3(2), 90-96. https://doi.org/10.31849/utamax.v3i2.6464

Nursafira, M. S. (2020). TED Talks in EFL Context: An Alternative Way for Teaching and Improving Student's Speaking Skills. Elsya : Journal of English Language Studies, 2(2), 43-47. https://doi.org/10.31849/elsya.v2i2.3968

O'Shea, S. (2016). Navigating the knowledge sets of older learners: Exploring the capitals of first-in-family mature age students. Widening Participation and Lifelong Learning, 18(3), 34-54.

Paterson, S., \& Stone, R. (2006). Educational leadership beyond behaviourism, the lessons we have learnt from art education. Australian Art Education, 29(1), 76-85.

Pitts, A. (2013). Learning from experience. Nursing Standard, 27(39)

Point Park University. (2016, April 22). Contrasting Classrooms: Instructional Differences
Purwanti, E. (2017). Understanding the EFL lecturers' beliefs about their professional learning from the lens of malcolm knowles theory of andragogy. Journal of Foreign Language Teaching and Learning, 2(1), 30-43.

Purwati, D. (2019). EFL teachers' challenges in teaching speaking in an Indonesian vocational high school. [Unpublished master's thesis]. The University of South Australia.

Purwati, D. (2020). Factors supporting and hindering the learning of English as an additional language experienced by a female Indonesian student. Jurnal Sains Sosio Humaniora, 4(1), 94-101.

Putri, S., \& Elihami, E. (2021). The concept andragogy and pedagogy: e-learning model during covid-19 pandemic. Jurnal Edukas iNonformal, 2(1), 18-24.

Saiful, J. A., \& Triyono, S. (2018). EFL teacher's reflection in teaching English to EFL students of rural areas. International Journal of Language Education, 2(2), 1-13.

Sharifi, M., Soleimani, H., \& Jafarigohar, M. (2017). E portfolio evaluation and vocabulary learning: Moving from pedagogy to andragogy. British Journal of Educational Technology, 48(6), 14411450 .

Smith, S., Ewing, R., \& Le, CR. (2015). Teaching: challenges \& dilemmas, 5th ed. Cengage Learning Australia: South Melbourne, Victoria.

Snyder, H. (2019). Literature review as a research methodology: An overview and guidelines. Journal of Business Research, 104, 333-339. https://doi.org/10.1016/j.jbusres.2019.07.039

Sumule, L. (2018). Implementing andragogy in Indonesian theological schools. Jurnal Jaffray, 16(1), 77-92.

Syamsuddin, S., \& Jimi, A. A. (2018). Implementing the principles of andragogy in ELT to enhance the students' English competence. EDUVELOP, 2(1), 57-63.

Tandon, K. (2016). Innovative andragogy: The paradigm shift to heutagogy. In Innovative Management Education Pedagogies for Preparing NextGeneration Leaders (pp. 238-257). IGI Global.

Wong, G., Greenhalgh, T., Westhorp, G., Buckingham, J., \& Pawson, R. (2013). RAMESES publication standards: Meta - narrative reviews. Journal of Advanced Nursing, 69(5), 987-1004. https://doi.org/10.1111/jan.12092. 